УДК 378.416

Аврамчук Антон Миколайович

аспірант

Інститут інформаційних технологій і засобів навчання НАПН України, м. Київ, Україна

ORCID ID 0000-0002-2868-0541

avramchuk92@gmail.com

\title{
МОДЕЛЬ РОЗВИТКУ КОМПЕТЕНТНОСТЕЙ ВИКЛАДАЧІВ МОВНИХ ДИСЦИПЛІН ЩОДО ПРОЕКТУВАННЯ МУЛЬТИМЕДІЙНИХ ЕЛЕКТРОННИХ OCВITHIX РЕСУРСІВ У СИСТЕМI MOODLE
}

\begin{abstract}
Анотація. Стаття присвячена проблемі розвитку компетентності викладачів мовних дисциплін щодо проектування мультимедійних електронних освітніх ресурсів у системі Moodle. Обгрунтовано і визначено поняття «компетентність викладачів мовних дисциплін щодо проектування мультимедійних електронних освітніх ресурсів у системі Moodle». Визначено й охарактеризовано компоненти і їх показники, за якими варто оцінювати рівні розвитку компетентності викладачів мовних дисциплін щодо проектування мультимедійних електронних освітніх ресурсів у системі Moodle. Розроблено модель розвитку компетентності викладачів мовних дисциплін щодо проектування мультимедійних електронних освітніх ресурсів у системі Moodle, яка базується на основних методологічних підходах, що використовуються в навчанні дорослих, і складається 3 п’яти блоків: цільовий, змістовий, технологічний, діагностичний та результативний.
\end{abstract}

Ключові слова: інформаційно-комунікаційні технології; мультимедійні електронні освітні ресурси; ІК-компетентність; модель.

\section{1. ВСТУП}

Постановка проблеми. На сьогодні одним із важливих і перспективних напрямів розвитку системи вищої освіти України $\epsilon$ організація й упровадження сучасних інформаційно-комунікаційних технологій (ІКТ), зокрема використання системи управління навчанням Moodle для організації самостійної позааудиторної роботи студентів у процесі вивчення мовних дисциплін, в освітній процес вищих навчальних закладів. Тому це зумовлює необхідність підготовки кваліфікованих і компетентних викладачів мовних дисциплін, які здатні до творчої діяльності, професійного самовдосконалення і використання різних ІКТ в освітньому процесі.

Аналіз останніх досліджень і публікацій. Проблеми використання IKT в освітньому процесі розглянуто у працях: В. Ю. Бикова, М. І. Жалдака, Т. І. Коваль, С. Г. Литвинової, Н. В. Морзе, О. В. Овчарук, О. В. Співаковського, О . М. Спіріна, М. П. Шишкіної та інших.

Проблеми використання ІКТ у процесі вивчення мовних дисциплін висвітлено у роботах І. І. Костікова, С. Ю. Ніколаєвої, Л. І. Морської, П. В. Сисоєва, Ю. І. Пассова, Є. С. Полат, J. Belz, S. Mills, L. Lеета ін.

Проектування, створювання та використання мультимедійних електронних освітніх ресурсів з мовних дисциплін присвячені роботи дослідників М. М. Боремчука, С. П. Кожушко, В. В. Коржа, Л. І. Скалій, О. Б. Тарнопольского, П .Ф Шпірко.

Мета статті: розробити й обгрунтувати модель розвитку компетентності викладачів мовних дисциплін щодо проектування мультимедійних електронних освітніх ресурсів у системі Moodle та визначити компоненти, за якими варто здійснювати оцінювання рівнів розвитку компетентності викладачів мовних дисциплін 
щодо проектування мультимедійних електронних освітніх ресурсів з мовних дисциплін у системі Moodle.

\section{2. РЕЗУЛЬТАТИ ДОСЛІДЖЕННЯ}

У даний час набуває поширення концепція компетентнісного підходу в освіті, що $\epsilon$ основою змістовних змін забезпечення відповідності освіти запитам і можливостям суспільства періоду інформатизації і глобальної масової комунікації. 3 позицій компетентнісного підходу суттю освіти стає розвиток здібності до самостійного рішення проблем урізних сферах і видах діяльності на основі використання соціального досвіду, елементом якого стає і власний досвід навчених. У системі безперервної освіти дорослих компетентність $є$ однією з основних характеристик результативності освіти в ланцюжку понять письменність - компетентність - культура - менталітет [1].

Для того щоб побудувати й обгрунтувати модель розвитку компетентності викладачів мовних дисциплін щодо проектування мультимедійних електронних освітніх ресурсів у системі Moodle, необхідно дослідити поняття «компетентність» і «ІК-компетентність».

Розглянемо поняття «компетентність» 3 урахуванням різних трактувань його змісту.

Науковець А. В. Хуторський визначає «компетентність» як сукупність особистісних якостей учня (ціннісно-смислових орієнтацій, знань, умінь, навичок, здібностей), зумовлених досвідом його діяльності у певній соціально й особистісно значущій сфері [2, с. 153].

О. В. Овчарук, після детального аналізу зарубіжних джерел зазначає, що «компетентність» - інтегрована характеристика якості особистості, результативний блок, сформований через досвід, знання, уміння, ставлення, поведінкові реакції [3, c. 13].

На державному рівні поняття «компетентність» у Законі «Про вищу освіту» визначено як динамічна комбінація знань, умінь і практичних навичок, способів мислення, професійних, світоглядних і громадянських якостей, морально-етичних цінностей, яка визначає здатність особи успішно здійснювати професійну і подальшу освітню діяльність і $є$ результатом навчання на певному рівні вищої освіти [4].

У проекті Тьюнінг «Гармонізація всіх освітніх структур в Європі» розрізняються загальні і фахові (предметні) компетентності майбутніх фахівців, і кінцеві результати навчання визначаються як певний рівень компетентності, якого повинен досягти студент. При цьому компетентності являють собою динамічне поєднання когнітивних i мета-когнітивних умінь і навичок, знань та розуміння, міжособистісних, розумових та практичних умінь і навичок та етичних цінностей [5].

Отже, проаналізувавши різні трактування поняття «компетентність», ми будемо визначати дане поняття як динамічне поєднання знань, розумінь, навичок, умінь та здатностей, що спрямовані на вирішення власних і професійних задач у певній галузі.

У Європейській рамці відповідності визначено вісім категорій ключових компетентностей, серед яких зазначено «цифрову компетентність», для навчання впродовж життя (Key Competences for Lifelong Learning - European Reference Framework) [6]:

1) спілкування рідною мовою (communication in the mother tongue);

2) спілкування іноземними мовами (communication in a foreign language);

3) математична грамотність i компетентність у галузі науки i технологій (mathematic literacy and basic competence in science and technology);

4) цифрова компетентність (digital competence); 
5) уміння навчатись (learning-to-learn);

6) соціальна та громадянська компетентності (social and civic competences);

7) відчуття ініціативи та підприємництва (sense of initiative and entrepreneurship);

8) культурна обізнаність та самовизначення (cultural awareness and expression).

Цифрова компетентність передбачає впевнене i критичне використання технологій інформаційного суспільства для роботи, відпочинку і спілкування [6]. Водночас у межах цієї компетентності розглядаються елементи інформаційнокомунікаційної компетентності, а саме: здатність пошуку, збору та оброблення інформації, іiі системного і критичного використання, оцінювання релевантності й відокремлення реального від віртуального під час використання певних посилань, уміння застосовувати інструменти, зокрема програмні засоби і послуги мережі Інтернет, для виробництва, презентації та розуміння інформації [7, с. 150].

Питанням, пов'язаним з виокремленням і трактуванням поняття інформаційнокомунікаційної компетентності, присвячені дослідження В. П. Вембера, М. І. Жалдака, О. Г. Кузьминської, Н. В. Морзе, О. В. Овчарук, О. М. Спіріна та ін.

Вітчизняні науковці Н. В. Морзе, В. П. Вембер, О. Г. Кузьмінська визначають, що ІК-компетентність передбачає здатність людини орієнтуватися в інформаційному просторі, оперувати даними на основі використання сучасних ІКТ відповідно до потреб ринку праці для ефективного виконання професійних обов'язків [8, с. 23].

О. В. Овчарук стверджує, що інформаційно-комунікаційна компетентність як ключова категорія розглядається як комплексне поняття, а саме - сукупність знань i розуміння, умінь, навичок, а також особистісних ставлень і ціннісних орієнтацій людини у галузі ІКТ та здатність автономно і відповідально демонструвати їх для практичної, професійної діяльності та навчання впродовж життя [3, с. 46].

Ми погоджуємось 3 визначенням, що ІК-компетентність - це підтверджена здатність особистості автономно і відповідально використовувати на практиці ІКТ для задоволення власних індивідуальних потреб і розв'язування суспільно значущих, зокрема професійних, задач у певній предметній галузі або виді діяльності [3, с. 46].

ІК-компетентність $€$ результатом різнобічних здатностей людини і має такі складові: здатності та вміння:

- здобувати інформацію з різних джерел у зрозумілому вигляді;

- працювати з різними відомостями;

- критично оцінювати відомості;

- використовувати у професійній діяльності IКТ; знання:

- основ ергономіки й інформаційної безпеки;

- функціональних можливостей IКТ;

- конкретні навички з використання комп'ютерної техніки та IКТ;

- ставлення особистості до застосування ІКТ для відповідальної соціальної взаємодії та поведінки (О. В. Овчарук, О. М. Спірін) [3, с. 46-48].

Отже, проаналізувавши викладений вище матеріал нашого дослідження, ми будемо розглядати розвиток компетентності викладачів мовних дисциплін щодо проектування мультимедійних електронних освітніх ресурсів у системі Moodle як складника ІК-компетентності. Звідси можна сформувати визначення «компетентність викладачів мовних дисциплін щеоо проектування мультимедійних електронних освітніх ресурсів у системі Mоodle» - це здатність проектувати мультимедійні електронні освітні ресурси 3 мовних дисциплін у середовищі системи Moodle з використанням спеціального інструментарію і модулів системи Moodle та впроваджувати в освітній процес вищих навчальних закладів. 
На підставі аналізу наукових досліджень і власного досвіду визначено компоненти та їхні показники, за якими варто здійснювати оцінювання рівнів розвитку компетентності викладачів мовних дисциплін щодо проектування мультимедійних електронних освітніх ресурсів з мовних дисциплін у системі Moodle.

1) Когнітивний компонент. Показники:

- знання змісту понять “мультимедійні електронні освітні ресурси”, “проектування мультимедійних електронних освітніх ресурсів 3 мовних дисциплін у системі Moodle";

- обізнаність щодо можливостей проектування мультимедійних електронних освітніх ресурсів 3 мовленнєвих видів діяльностей (аудіювання, говоріння, читання, письмо) у системі Moodle для розв'язання професійних завдань;

- володіння знаннями щодо використання мультимедійних електронних освітніх pecyрсів з мовних дисциплін у системі Moodle, які необхідні в професійній діяльності.

2) Діяльнісний компонент. Показники:

- здатність проектувати і використовувати мультимедійні електронні освітні ресурси $з$ мовних дисциплін у системі Moodle для розв'язання професійних завдань у педагогічній діяльності;

- здатність організовувати освітній процес 3 мовних дисциплін за допомогою мультимедійних електронних освітніх ресурсів у системі Moodle;

- здатність організовувати комунікацію зі студентами під час викладання мовних дисциплін за допомогою мультимедійного інструментарію системи Moodle.

3) Мотиваційний компонент. Показники:

- потреба в якісній організації освітнього процесу з мовних дисциплін у системі Moodle;

- прояв зацікавленості щодо проектування мультимедійних електронних освітніх ресурсів з мовних дисциплін у системі Moodle;

- прагнення до підвищення кваліфікації і професійного самовдосконалення 3 проблеми проектування мультимедійних електронних освітніх ресурсів 3 мовних дисциплін у системі Moodle.

4) Адаптивний компонент. Показники:

- пристосування до нових вимог суспільства;

- розвиток здібностей щодо оволодіння системою управління навчанням Moodle;

- розуміння викладачем новизни і доцільності проектування мультимедійних електронних освітніх ресурсів з мовних дисциплін у системі Moodle;

- швидке реагування викладача на появу нових IКТ для проектування мультимедійних електронних освітніх ресурсів з мовних дисциплін у системі Moodle.

Відповідно до зазначених характеристик когнітивного, діяльнісного, мотиваційного, адаптивного компонентів, надамо їх характеристики для трьох рівнів (низький, середній і високий), що представлено у табл. 1, 2, 3, 4.

Таблиия 1

\section{Характеристика рівнів когнітивного компонента та його показників компетентності викладачів мовних дисциплін щодо проектування мультимедійних електронних освітніх ресурсів у системі Moodle}

\begin{tabular}{|c|c|}
\hline Рівні & \multicolumn{1}{|c|}{ Характеристика } \\
\hline Низький & $\begin{array}{l}\text { Відсутність знань щодо змісту понять: “мультимедійні електронні освітні } \\
\text { ресурси”, “проектування мультимедійних електронних освітніх ресурсів } 3 \\
\text { мовних дисциплін у системі Мoodle”. }\end{array}$ \\
\hline
\end{tabular}




\begin{tabular}{|c|c|}
\hline & $\begin{array}{l}\text { - Не обізнаний щодо можливостей проектування мультимедійних електронних } \\
\text { освітніх ресурсів } 3 \text { мовленнєвих видів діяльностей у системі Moodle для } \\
\text { розв'язання професійних завдань. } \\
\text { - Не володіє знаннями щодо використання мультимедійних електронних } \\
\text { освітніх ресурсів } 3 \text { мовних дисциплін у системі Moodle, які необхідні в } \\
\text { професійній діяльності }\end{array}$ \\
\hline Середній & $\begin{array}{l}\text { - Розуміє зміст понять: “мультимедійні електронні освітні ресурси”, } \\
\text { “проектування мультимедійних електронних освітніх ресурсів } 3 \text { мовних } \\
\text { дисциплін у системі Моодlе”. } \\
\text { - Має уявлення щодо можливостей проектування мультимедійних електронних } \\
\text { освітніх ресурсів } 3 \text { мовленнєвих видів діяльностей у системі Moodle для } \\
\text { розв’язання професійних завдань. } \\
\text { - Має уявлення щодо використання мультимедійних електронних освітніх } \\
\text { ресурсів } 3 \text { мовних дисциплін у системі Moоdle, які необхідні в професійній } \\
\text { діяльності }\end{array}$ \\
\hline Високий & $\begin{array}{l}\text { - Має чіткі знання щодо змісту понять: мультимедійні електронні освітні } \\
\text { ресурси”, “проектування мультимедійних електронних освітніх ресурсів } 3 \\
\text { мовних дисциплін у системі Моodle”. } \\
\text { - Чітко обізнаний щодо можливостей проектування мультимедійних } \\
\text { електронних освітніх ресурсів } 3 \text { мовленнєвих видів діяльностей у системі } \\
\text { Моodle для розв’язання професійних завдань. } \\
\text { - Чікко володіє знаннями щодо використання мультимедійних електронних } \\
\text { освітніх ресурсів з мовних дисциплін у системі Мооде, які необхідні в } \\
\text { професійній діяльності }\end{array}$ \\
\hline
\end{tabular}

Таблиия 2

\section{Характеристика рівнів діяльнісного компонента та його показників компетентності викладачів мовних дисциплін щодо проектування мультимедійних електронних освітніх ресурсів у системі Moodle}

\begin{tabular}{|c|c|}
\hline Рівні & Характеристика \\
\hline Низький & $\begin{array}{l}\text { - Не вміє проектувати і використовувати мультимедійні електронні освітні } \\
\text { ресурси з мовних дисциплін у системі Moodle для розв'язання професійних } \\
\text { завдань у педагогічній діяльності. } \\
\text { - Не вміє організовувати освітній процес з мовних дисциплін за допомогою } \\
\text { мультимедійних електронних освітніх ресурсів у системі Моodle. } \\
\text { - Не вміє організовувати комунікацію зі студентами під час викладання } \\
\text { мовних дисциплін за допомогою мультимедійного інструментарію системи } \\
\text { Moodle }\end{array}$ \\
\hline Середній & $\begin{array}{l}\text { - Уміє проектувати і використовувати деякі мультимедійні електронні освітні } \\
\text { ресурси з мовних дисциплін у системі Moodle для розв'язання професійних } \\
\text { завдань у педагогічній діяльності. } \\
\text { - Частково організовує освітній процес } 3 \text { мовних дисциплін за допомогою } \\
\text { мультимедійних електронних освітніх ресурсів у системі Moodle. } \\
\text { - Частково організовує комунікацію зі студентами під час викладання мовних } \\
\text { дисциплін за допомогою мультимедійного інструментарію системи Moodle. }\end{array}$ \\
\hline Високий & $\begin{array}{l}\text { - Упевнено проектує і використовує різні мультимедійні електронні освітні } \\
\text { ресурси з мовних дисциплін у системі Moodle для розв’язання професійних } \\
\text { завдань у педагогічній діяльності. } \\
\text { - Уміє організовувати освітній процес } 3 \text { мовних дисциплін за допомогою } \\
\text { мультимедійних електронних освітніх ресурсів у системі Моodle. } \\
\text { - Уміє організовувати комунікацію зі студентами під час викладання мовних } \\
\text { дисциплін за допомогою мультимедійного інструментарію системи Moodle }\end{array}$ \\
\hline
\end{tabular}




\section{Характеристика рівнів мотиваційного компонента та його показників компетентності викладачів мовних дисциплін щодо проектування мультимедійних електронних освітніх ресурсів у системі Moodle}

\begin{tabular}{|c|c|}
\hline Рівні & Характеристика \\
\hline Низький & $\begin{array}{l}\text { - Не потребує організації освітнього процесу з мовних дисциплін у системі } \\
\text { Моодlе. } \\
\text { - Не має прояву зацікавленості щодо проектування мультимедійних } \\
\text { електронних освітніх ресурсів } 3 \text { мовних дисциплін у системі Моodle. } \\
\text { - Не прагне до підвищення кваліфікації і професійного самовдосконалення } 3 \\
\text { проблеми проектування мультимедійних електронних освітніх ресурсів } 3 \\
\text { мовних дисциплін у системі Moodle }\end{array}$ \\
\hline Середній & $\begin{array}{l}\text { - Має позитивне ставлення щодо організації освітнього процесу з мовних } \\
\text { дисциплін у системі Моodle. } \\
\text { - Усвідомлює необхідність щодо проектування мультимедійних електронних } \\
\text { освітніх ресурсів з мовних дисциплін у системі Моodle. } \\
\text { - Усвідомлює необхідність щодо підвищення кваліфікації і професійного } \\
\text { самовдосконалення з проблеми проектування мультимедійних електронних } \\
\text { освітніх ресурсів з мовних дисциплін у системі Мoodle }\end{array}$ \\
\hline Високий & $\begin{array}{l}\text { - Має чітке розуміння у потребі організації освітнього процесу з мовних } \\
\text { дисциплін у системі Мооде. } \\
\text { - Має чітке розуміння у потребі проектування мультимедійних електронних } \\
\text { освітніх ресурсів з мовних дисциплін у системі Мооdle. } \\
\text { - Має чітке розуміння у потребі підвищення кваліфікації і професійного } \\
\text { самовдосконалення з проблеми проектування мультимедійних електронних } \\
\text { освітніх ресурсів } 3 \text { мовних дисциплін у системі Моodle }\end{array}$ \\
\hline
\end{tabular}

Таблиия 4

\section{Характеристика рівнів адаптивного компонента та його показників компетентності викладачів мовних дисциплін щодо проектування мультимедійних електронних освітніх ресурсів у системі Moodle}

\begin{tabular}{|c|c|}
\hline Рівні & Характеристика \\
\hline Низький & $\begin{array}{l}\text { - Не пристосований до нових вимог суспільства; } \\
\text { - Не розвиває здібності щодо оволодіння системою управління навчанням } \\
\text { Мооdle; } \\
\text { - Не розуміє новизни й доцільності проектування мультимедійних електронних } \\
\text { освітніх ресурсів з мовних дисциплін у системі Моodle; } \\
\text { - Не реагує на появу нових ІКТ для проектування мультимедійних } \\
\text { електронних освітніх ресурсів } 3 \text { мовних дисциплін у системі Мoodle }\end{array}$ \\
\hline Середній & $\begin{array}{l}\text { - Частково пристосований до нових вимог суспільства; } \\
\text { - Частково розвиває здібності щодо оволодіння системою управління } \\
\text { навчанням Моодle; } \\
\text { - Частково розуміє новизну й доцільність проектування мультимедійних } \\
\text { електронних освітніх ресурсів з мовних дисциплін у системі Моodle; } \\
\text { - Частково реагує на появу нових ІКТ для проектування мультимедійних } \\
\text { електронних освітніх ресурсів з мовних дисциплін у системі Мoodle }\end{array}$ \\
\hline Високий & $\begin{array}{l}\text { - Повністю пристосований до нових вимог суспільства; } \\
\text { - Повністю розвинені здібності щодо оволодіння системою управління } \\
\text { навчанням Моодle; } \\
\text { - Повністю розуміє новизну й доцільність проектування мультимедійних } \\
\text { електронних освітніх ресурсів з мовних дисциплін усистемі Моодlе; } \\
\text { - Повністю реагує на появу нових IКТ для проектування мультимедійних } \\
\text { електронних освітніх ресурсів з мовних дисциплін у системі Moodle }\end{array}$ \\
\hline
\end{tabular}


Для забезпечення розвитку компетентності викладачів мовних дисциплін щодо проектування мультимедійних електронних освітніх ресурсів у системі Moodle можна використовувати моделювання як метод наукового дослідження.

Моделюванням називається дослідження явищ, процесів чи систем за допомогою побудови та вивчення їхніх моделей, а також використання цих моделей для визначення й уточнення характеристик і раціоналізації способів побудови об'єктів, що конструюються[9].

В. Ю. Бикова зазначає, що модель - це деяке подання системи, у якому відображаються, враховуються, характеризуються і можуть відтворюватися такі особливості цієї системи, які забезпечують досягнення цілей побудови та використання моделі [10, с. 232].

Отже, педагогічне моделювання є одним із важливих етапів діяльності педагогадослідника. За допомогою моделі можливо оцінити результати своєї діяльності, порівняти наслідки усіх наступних кроків, зосередити увагу не на всьому об'єкті дослідження, а саме на тому, що його в цьому об'єкті цікавить.

Тому на основі аналізу наукових і методичних джерел було розроблено модель розвитку компетентності викладачів мовних дисциплін щодо проектування мультимедійних електронних освітніх ресурсів у системі Moodle (рис. 1). Вона складається з цільового, змістового, технологічного, діагностичного, результативного блоку і вміщує методологічні підходи і принципи навчання.

Перш за все, модель базується на інформаційно-освітньому середовищі вищого навчального закладу (ВН3) на основі системи Moodle. На основі аналізу поняття інформаційно-освітнього середовища вченими (А. Ахаян, О. Зайцева, І. Захарова, О. Ільченко, В. Красильнікова, Л. Панченко І. Роберт, Е. Семенюк, О. Соколова та ін.) ми прийшли до висновку, що під інформаційно-освітнім середовищем ВНЗ ми будемо вважати створену у ВНЗ систему навчання, яка об'єднує інтелектуальні, культурні, навчально-методичні, інформаційні, організаційні і технічні ресурси та забезпечує розвиток пізнавальної та творчої діяльності тих, хто навчається.

Одним із головних аспектів успішного створення інформаційно-освітнього середовища ВНЗ є вибір електронної навчальної платформи для організації навчальновиховного процесу й управління вищим навчальним закладом.

Важливим чинником вибору електронної навчальної платформи $є$ іiі ціна i функціональні можливості. Тому багато університетів світу та України зупинили свій вибір на електронній навчальній платформі Moodle, яка розповсюджується безкоштовно як OpenSource-проект (ліцензія GNUGPL) [11].

Moodle (акронім від Modular Object-Oriented Dynamic Learning Environment модульне об'єктно-орієнтоване динамічне навчальне середовище) - навчальна платформа, призначена для об’єднання педагогів, адміністраторів і учнів (студентів) в одну надійну, безпечну та інтегровану систему для створення персоналізованого навчального середовища [11].

Навчальне середовище Moodle надійна в експлуатації; є простою у використанні та адмініструванні; забезпечує безпеку інформації (встановлення паролів, обробка форм даних, зберігання інформації у базі даних) та передачу даних від викладача до студента; здійснює оцінювання навчальних досягнень студентів; сумісна зі стандартним програмним забезпеченням; містить більше двадцяти типів ресурсів i програмних засобів (базовий комплект); проектувалася відповідно до реалізації методів колективної діяльності студентів; iї інтерфейс має переклади на 70 іноземних мов [12].

Перший блок моделі є циільовим, що включає мету: розвиток компетентності викладачів мовних дисциплін щодо проектування мультимедійних електронних освітніх ресурсів у системіMoodle. 
Інформаційно-осєітне середоєище ВНЗ на основі системи Moodle

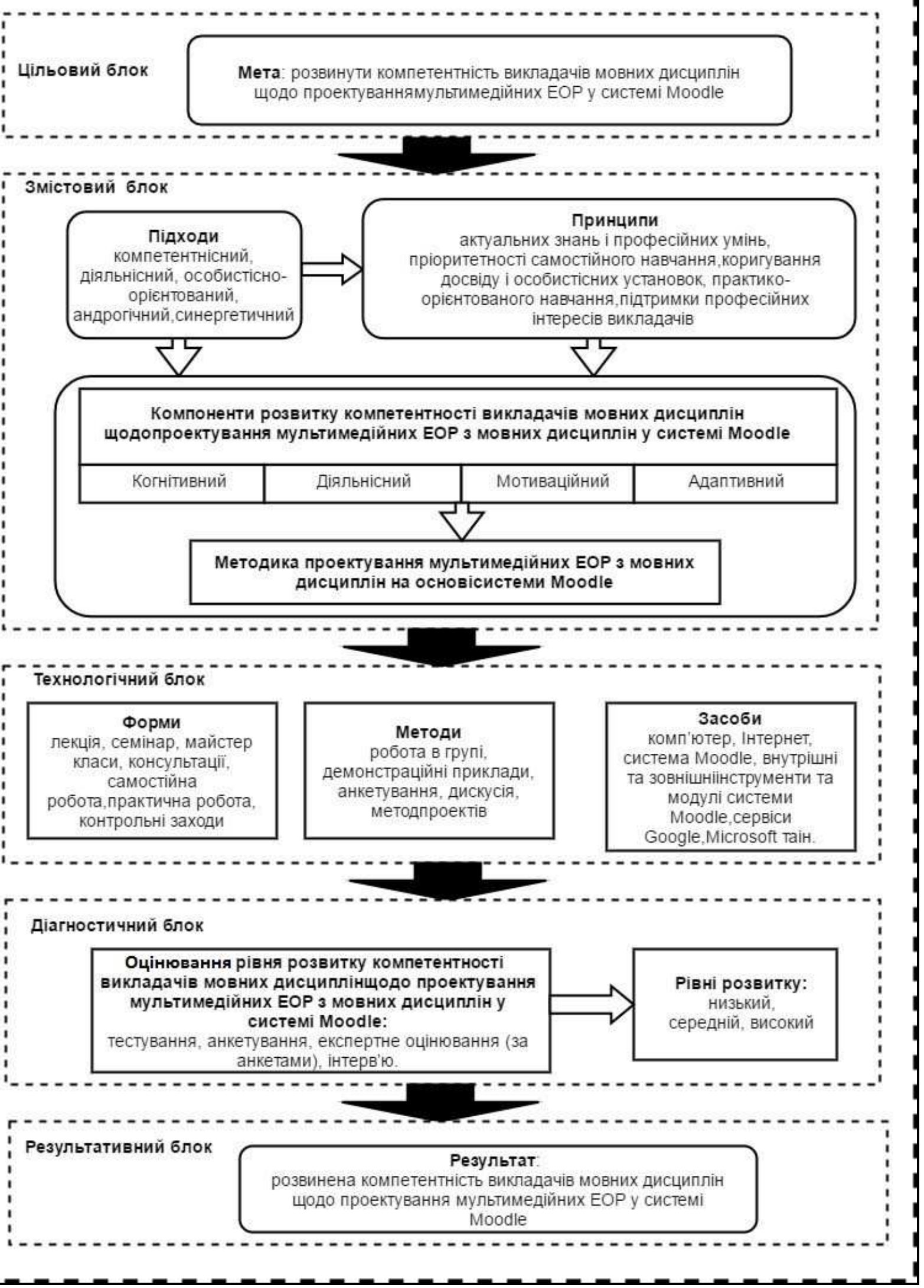

Рис. 1. Модель розвитку компетентності викладачів мовних дисциплін щуодо проектування мультимедійних електронних освітніх ресурсів у системі Moоdle 
Другий блок моделі $\epsilon$ змістовим і включає наукові підходи розвитку компетентності викладачів мовних дисциплін щодо проектування мультимедійних електронних освітніх ресурсів у системи Moodle, а саме: компетентнісний, діяльнісний, особистісно-орієнтований, андрогічний, синергетичний; принципи, що диктуються зазначеними підходами: актуальних знань і професійних умінь, пріоритетності самостійного навчання, коригування досвіду й особистісних установок, практикоорієнтованого навчання, підтримки професійних інтересів викладачів; компоненти: когнітивний, діяльнісний, мотиваційний та адаптивний.

Третій блок - технологічний, який базується на формах (лекція, семінар, майстер класи, консультації, самостійна робота, практична робота, контрольні заходи), методах (робота в групі, демонстраційні приклади, анкетування, дискусія, метод проектів) i засобах навчання (комп'ютер, Інтернет, система Moodle, внутрішні та зовнішні інструменти та модулі системи Moodle, сервіси Google,Microsoftта ін.).

Четвертий блок моделі - діагностичний. Він включає методи оцінювання розвитку компетентності: тестування, анкетування, експертне оцінювання (за анкетами), інтерв'ю для визначення рівнів розвитку компетентності викладачів мовних дисциплін щодо проектування мультимедійних електронних освітніх ресурсів у системі Moodle: низький, середній, високий.

П'ятий блок моделі - результативний. Результатом моделі $є$ розвинена компетентність викладачів мовних дисциплін щодо проектування мультимедійних електронних освітніх ресурсів у системі Moodle.

\section{3. ВИСНОВКИ ТА ПЕРСПЕКТИВИ ПОДАЛЬШИХ ДОСЛІДЖЕНЬ}

Отже, розвиток компетентності викладачів мовних дисциплін щодо проектування мультимедійних електронних освітніх ресурсів у системі Moodle доцільно здійснювати на основі запропонованої моделі з урахуванням визначених компонентів, показників та рівнів.

Розроблена модель розвитку компетентності викладачів мовних дисциплін щодо проектування мультимедійних електронних освітніх ресурсів у системі Moodle містить цільовий, змістовий, технологічний, діагностичний та результативний блоки. Цільовий блок відображає мету моделі. Змістовий блок включає наукові підходи (компетентнісний, діяльнісний, особистісно-орієнтований, андрогічний, синергетичний) трозвитку компетентності викладачів мовних дисциплін щодо проектування мультимедійних електронних освітніх ресурсів у системі Moodle та принципи, які диктуються зазначеними підходами. Визначено компоненти (когнітивний, діяльнісний, мотиваційний, адаптивний) та показники, за якими доцільно здійснювати оцінювання рівнів розвитку компетентності викладачів мовних дисциплін щодо проектування мультимедійних електронних освітніх ресурсів 3 мовних дисциплін у системі Moodle. Технологічний блок базується на формах, методах і засобах навчання викладачів мовних дисциплін щодо проектування мультимедійних електронних освітніх ресурсів з мовних дисциплін у системі Moodle. Діагностичний блок дозволяє оцінити рівень (низький, середній, високий) розвитку компетентності викладачів мовних дисциплін щодо проектування мультимедійних електронних освітніх ресурсів у системі Moodle. Результативний блок відображає результат, який має бути отриманий із застосуванням побудованої моделі.

Отже, у разі застосування даної моделі в освітньому процесі вищих навчальних закладах, викладачі мовних дисциплін будуть розвивати свій рівень компетентності щодо проектування мультимедійних електронних освітніх ресурсів у системі Moodle. 
Перспективою подальших наукових досліджень є розробка відповідної методики щодо проектування мультимедійних електронних освітніх ресурсів з мовних дисциплін на основі системи Moodle.

\title{
СПИСОК ВИКОРИСТАНИХ ДЖЕРЕЛ
}

[1] Формування та розвиток ІКТ-компетентності педагогів, 2017. [Електронний ресурс]. Доступно: http://wiki.ciit.zp.ua/index.php/Формування_та_розвиток_ІКТ-компетентності_педагогів.

[2] А. Хуторский, "Ключевые компетенции как компонент личностно-ориентированной парадигмы образования", Ученик в общеобразовательной школе, с. 135-157, 2002.

[3] В. Ю. Биков та ін., Основи стандартизації інформачійно-комунікаційних компетентностей в системі освіти України. Київ, Україна: Атіка, 2010.

[4] Верховна Рада України, (2014, Лип. 01). Закон № 1556-VII, Закон України «Про вищу освіту». [Електронний ресурс]. Доступно: http://zakon4.rada.gov.ua/laws/show/155618/page?text=\%E2\%E5.

[5] Проект "Тьюнінг", 2017 [Електронний ресурс] Доступно: http://www.unideusto.org/tuningeu/images/stories/documents/General_Brochure_Ukrainian_version.pdf.

[6] European Union, "Key Competencies for Lifelong Learning", Official Journal of the European Union, pp. 10-18, 2006.

[7] О. В. Білоус та О. О. Гриценчук, Формування інформаційно-комунікаційних компетентностей у контексті євроінтеграціийних процесів створення інформаційного освітнього простору. Київ, Україна: Атіка, 2014.

[8] Н. В. Морзе та В. П. Вембер, Інформатика 9 клас. Київ, Україна: УВЦ «Школяр», 2009.

[9] Сутність моделювання та поняття моделі, 2017. [Електронний ресурс] - Доступно: http://om.net.ua/18/18_3/18_34838_sushchnost-modelirovaniya-ponyatie-modeli.html.

[10] В. Ю. Биков, Моделі організаційних систем відкритої освіти. Київ, Україна: Атіка, 2009.

[11] Moodle, 2017. [Електронний ресурс]. - Доступно: http://moodle.org.

[12] Т. І. Коваль, "Особливості проектування інформаційно-освітнього полікультурного середовища педагогічного університету", 2013. [Електронний ресурс]. Доступно: http://lib.iitta.gov.ua/1318/1/1_\%D0\%9A\%D0\%BE\%D0\%B2\%D0\%B0\%D0\%BB\%D1\%8C.pdf.

Матеріал надійшов до редакиї 21.08.2017 p.

\section{МОДЕЛЬ РАЗВИТИЯ КОМПЕТЕНТНОСТЕЙ ПРЕПОДАВАТЕЛЕЙ ЯЗЫКОВЫХ ДИСЦИПЛИН ПО ПРОЕКТИРОВАНИЮ МУЛЬТИМЕДИЙНЫХ ЭЛЕКТРОННЫХ ОБРАЗОВАТЕЛЬНЫХ РЕСУРСОВ В СИСТЕМЕ МООDLЕ}

\author{
Аврамчук Антон Михайлович \\ аспирант \\ Институт информационных технологий и средств обучения НАПН Украины, г. Киев, Украина \\ ORCID ID 0000-0002-2868-0541 \\ avramchuk92@gmail.com
}

\begin{abstract}
Аннотация. Статья посвящена проблеме развития компетентности преподавателей языковых дисциплин по проектированию мультимедийных электронных образовательных ресурсов в системе Moodle. Обоснованно и определено понятие «компетентность преподавателей языковых дисциплин по проектированию мультимедийных электронных образовательных ресурсов в системе Moodle». Определены и охарактеризованы компоненты, по которым следует оценивать уровни развития компетентности преподавателей языковых дисциплин по проектированию мультимедийных электронных образовательных ресурсов в системе Moodle. Разработана модель развития компетентности преподавателей языковых дисциплин по проектированию мультимедийных электронных образовательных ресурсов в системе Moodle, которая базируется на основных научных подходах, используемых в обучении взрослых, и состоит из пяти блоков: целевой, содержательный, технологический, диагностический и результативный.
\end{abstract}

Ключевые слова: информационно-коммуникационные технологии; мультимедийные электронные образовательные ресурсы; ИК- компетентность; модель. 


\title{
THE MODEL OF LINGUISTIC TEACHERS' COMPETENCY DEVELOPMENT ON DESIGNING MULTIMEDIA ELECTRONIC EDUCATIONAL RESOURCES IN THE MOODLE SYSTEM
}

\author{
Anton M. Avramchuk \\ Ph.D student \\ Institute of Information Technologies and Learning Tools of the NAES of Ukraine, Kyiv, Ukraine \\ ORCID ID 0000-0002-2868-0541 \\ avramchuk92@gmail.com
}

\begin{abstract}
The article is devoted to the problem of developing the competency of teachers of language disciplines on designing multimedia electronic educational resources in the Moodle system. The concept of "the competence of teachers of language disciplines on designing multimedia electronic educational resources in the Moodle system" is justified and defined. Identified and characterized the components by which the levels of the competency development of teachers of language disciplines on designing multimedia electronic educational resources in the Moodle system should be assessed. Developed a model for the development of the competency of teachers of language disciplines on designing multimedia electronic educational resources in the Moodle system, which is based on the main scientific approaches, used in adult education, and consists of five blocks: target, informative, technological, diagnostic and effective.
\end{abstract}

Keywords: information and communication technologies; multimedia electronic educational resources; IC-competency; model.

\section{REFERENCES (TRANSLATED AND TRANSLITERATED)}

[1] Formation and development of ICT-competence of teachers, 2017. [Online]. Available: http://wiki.ciit.zp.ua/index.php/Формування_та_розвиток_ІКТ-компетентності_педагогів. (in Ukrainian)

[2] A. Khutorskyi, "Key competencies as a component of a person-orientedparadigm of education", Uchenyk v obshcheobrazovatelnoishkole, p. 135-157, 2002. (in Russian)

[3] V.Yu. Bykov etal., Fundamentals of standardization of information and communication competences in the educationsystem of Ukraine. Kyiv, Ukraine: Atika, 2010. (in Ukrainian)

[4] Verkhovna Rada of Ukraine(2014, Jul 01). Law No. 1556-VII, Law of Ukraine "On Higher Education". [Online]. Available: http://zakon4.rada.gov.ua/laws/show/155618/page?text=\%E2\%E5. (in Ukrainian)

[5] "Tuning" Project, $\quad 2017 \quad$ [Online]. Available:http://www.unideusto.org/tuningeu/images/stories/documents/General_Brochure_Ukrainian_ve rsion.pdf.(in Ukrainian)

[6] European Union, "Key Competencies for Lifelong Learning", Official Journal of the European Union, pp. 10-18, 2006.(in English)

[7] O.V. Bilous and O.O. Grytsenchuk, Formation of information and communication competences in the context of eurointegration processes for creation of information educational space. Kyiv, Ukraine: Atika, 2014.(in Ukrainian)

[8] N.V. Morze and V.P. Vember, Computer Science 9th form. Kyiv, Ukraine: UVTs «Shkolyar», 2009.(in Ukrainian)

[9] The essence of modeling and concept of model, 2017. [Online] - Available: http://om.net.ua/18/18_3/18_34838_sushchnost-modelirovaniya-ponyatie-modeli.html(inUkrainian)

[10] V.Yu. Bykov, The models of open education organizational systems. Kyiv, Ukraine: Atika, 2009. (in Ukrainian).

[11] Moodle, 2017. [Online]. - Available: http://moodle.org.(in English)

[12] T.I. Koval, "Features of the designing of information and educational multicultural environment of the $\begin{array}{lll}\text { pedagogical } & 2013 & \text { university", }\end{array}$ Available:http://lib.iitta.gov.ua/1318/1/1_\%D0\%9A\%D0\%BE\%D0\%B2\%D0\%B0\%D0\%BB\%D1\%8C.p df.(in Ukrainian)

\section{(c) BY-NC-SA}

ThisworkislicensedunderCreativeCommonsAttribution-NonCommercial-ShareAlike 4.0 InternationalLicense. 